The definitive, peer-reviewed and edited version of this article is published and can be cited as

Santos, G. and T. Catchesides (2005), 'Distributional Consequences of Gasoline Taxation in the United Kingdom', Transportation Research Record, $\mathrm{N}^{\circ} 1924$, pp. 103-111. DOI: 10.3141/1924-13

\title{
Distributional consequences of gasoline taxation in the UK
}

\section{Georgina Santos and Tom Catchesides}

\author{
Georgina Santos \\ Transport Studies Unit \\ University of Oxford \\ Oxford, OX2 6NB, UK \\ Tel: + 441865274717 \\ Fax: + 441865515194 \\ Georgina.Santos@tsu.ox.ac.uk \\ Tom Catchesides \\ Unit 313, 48 Regent St \\ Cambridge, CB2 1FD, UK \\ Tel: + 447881952510 \\ Tom@Catchesides.co.uk
}

February 28, 2005 


\title{
Distributional consequences of gasoline taxation in the UK
}

\author{
Georgina Santos and Tom Catchesides
}

\begin{abstract}
This paper assesses the regressive effects of gasoline taxation in the UK. When all households are considered, middle-income households suffer most of the burden. When only car-owning households are considered gasoline taxation is strongly regressive. Low-income households that own a car are more severely affected than high income ones because they spend a larger proportion of their income on motoring. This conclusion is similar to that from previous studies on the topic.
\end{abstract}

\section{KEY WORDS}

Fuel taxes. Fuel duties. Regressive impacts. Gasoline taxation.

\section{INTRODUCTION}

The fuel protests that brought parts of the UK's road network to a standstill in the summer of 2000 prompted a renewed interest in both the level of gasoline taxation and its distributional consequences amongst the general public. While real fuel duty rose steadily throughout the 1990 s, so that taxation at its peak accounted for almost $86 \%$ of the retail price of unleaded gasoline in March 1999, concern arose over the effects of gasoline taxation upon low-income groups and those living in rural areas.

This paper analyzes the regressivity of fuel taxation in the UK. The results show that when all households are considered, middle-income households suffer most of the burden and that when only car-owning households are considered gasoline taxation is strongly regressive. This conclusion is very much in line with previous work on the topic.

Johnson et al (1) analyze the distributional effects of increases in fuel duties in the UK using simulation results from a consumer demand model. They conclude that the effects are progressive because car-ownership is much lower amongst low-income groups. Wiese et al (2) conclude that the greater the proportion of motor-fuel tax revenue devoted to general uses, the greater is the absolute and relative burden of the lowest income household, and the more regressive is the policy with respect to the overall distributional structure. Blow and Crawford (3) find that rising fuel taxes is progressive if all households are considered but regressive if only car owning households are considered. Asensio et al (4) use micro data from the Spanish Household Budget Survey of 1990/91 and show that fuel taxes are regressive, and the degree of regressiveness raises the smaller the size of the municipality considered. For the smallest municipalities they find the most regressive effects. On the other hand they do find that fuel taxes seem to be slightly progressive in the largest cities of their sample. Blow and Crawford (3) also observe that the effect of a duty increase falls with population density, probably because there are better substitutes for private motoring.

All these studies show that in general, when car-owning households are considered fuel taxes are regressive. In this paper newer data is used to provide an updated view of the distributional consequences of gasoline taxation in the UK, and the potential consequences if fuel duties were 
increased. There were plans to increase duties in September 2004 but these were postponed, mainly because of the high and volatile world oil prices.

\section{Fuel Tax Policy in the UK 1993-2004}

The rising share of taxation in the retail price of road fuel between 1993 and 1999 was due to automatic increases in fuel duty of a fixed percentage over inflation, a mechanism known as the 'escalator', introduced by the Conservatives and continued by the Labour Government. Although the actual reason for the fuel escalator was the need for revenues, the Government claimed the idea was to reduce traffic growth and emissions. In the March 1993 Budget, this escalator was set at $3 \%$ before being increased to $5 \%$ the following November. The escalator was increased to 6\% in March 1997 and abolished in November 1999, with any further increases to be decided on a Budget-by-Budget basis.

In the summer and autumn of 2000, there was an increase in the world price of crude oil, which combined with high fuel taxes, caused an important increase in the final price of fuel, as shown on Figure 1. This resulted in a fuel tax protest that triggered shortages, panic buying and traffic chaos across the UK. Although the economic self-interest of the motoring majority clearly played a role in the fuel crisis, much of the language used by the protestors was couched in terms of concern for low-income and rural households, who were widely perceived as suffering disproportionately from rising gasoline prices (5).

Figure 1 shows the three components of the retail price of unleaded gasoline, the pre-tax price, duty and Value Added Tax, which is applied to the sum of the pre-tax price and duty, for the period January 1990 - October 2004. It can be seen that, although an increase in the pre-tax price of unleaded gasoline was responsible for much of the rise in its retail price in the run-up to the summer of 2000, the share of the retail price attributable to taxation rose steadily throughout the 1990s. In October 2000 the fuel duty on ultra-low sulphur gasoline, which at the time was difficult to find at gasoline stations, was cut down by 1 pence per litre. In March 2001 it was further cut down by two pence and this is the reduction that can be seen on the figure. At that point most drivers switched from unleaded gasoline to unleaded ultra-low sulphur gasoline, and so the rest of the graph refers to ultra-low sulphur gasoline, which accounts for virtually all unleaded gasoline sold in the UK. In October 2003 the duty was increased by 2 pence per litre and it remained at that level until October 2004. As of November 2004 there have been no further changes. 
FIGURE 1 Components of the retail price of unleaded gasoline

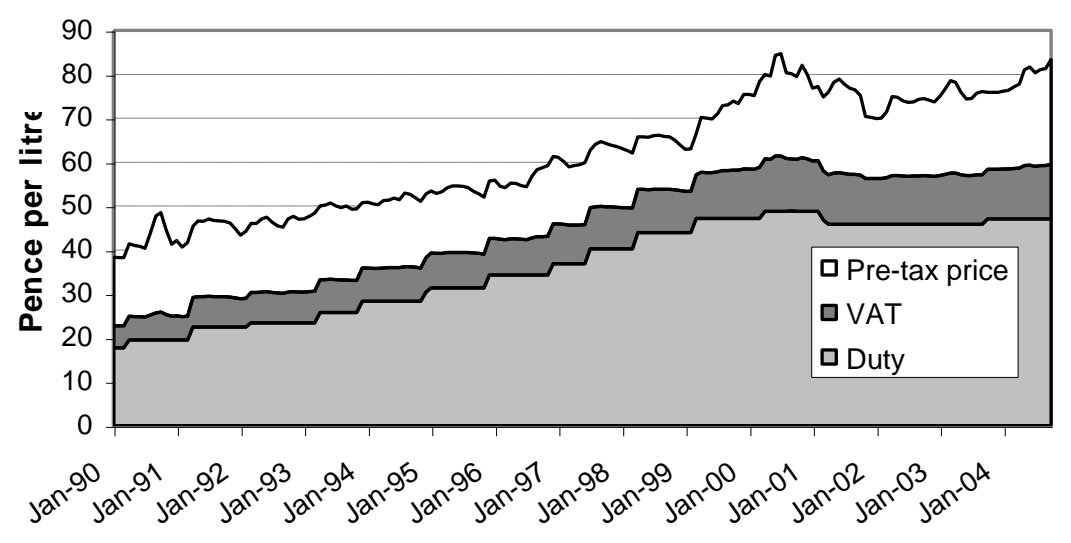

Source: Department of Trade and Industry, Quarterly Energy Prices Update, October 2004 (Table 4.1.1: Typical monthly retail prices of gasolineeum products and a crude oil price index, www.dti.gov.uk/energy/inform/energy_prices/\#listoftables)

\section{THE DISTRIBUTIONAL EFFECTS OF GASOLINE TAXATION}

Figures 2 and 3 plot an Engel curve of the share of road fuel expenditure in income for households in the UK. Figure 2 plots the relationship for all households, while Figure 3 does the same for car-owning households alone. From Figure 2, it would seem that road fuel is a luxury for low-income households (because the budget share of road fuel increases with income) and a necessity for high-income households (because the budget share of road fuel generally decreases with income). However, Figure 3 shows that road fuel is a necessity for car-owning households because the budget share of road fuel consistently declines with income. The difference between these two figures can be attributed to low levels of car-ownership among lower-income households: although road fuel occupies a large proportion of poorer car-owning households' income, the fact that relatively few low-income households own cars means that, when all households are considered, road fuel accounts for a relatively small share of their incomes. 
FIGURE 2 Income share of gasoline costs for all households by income decile

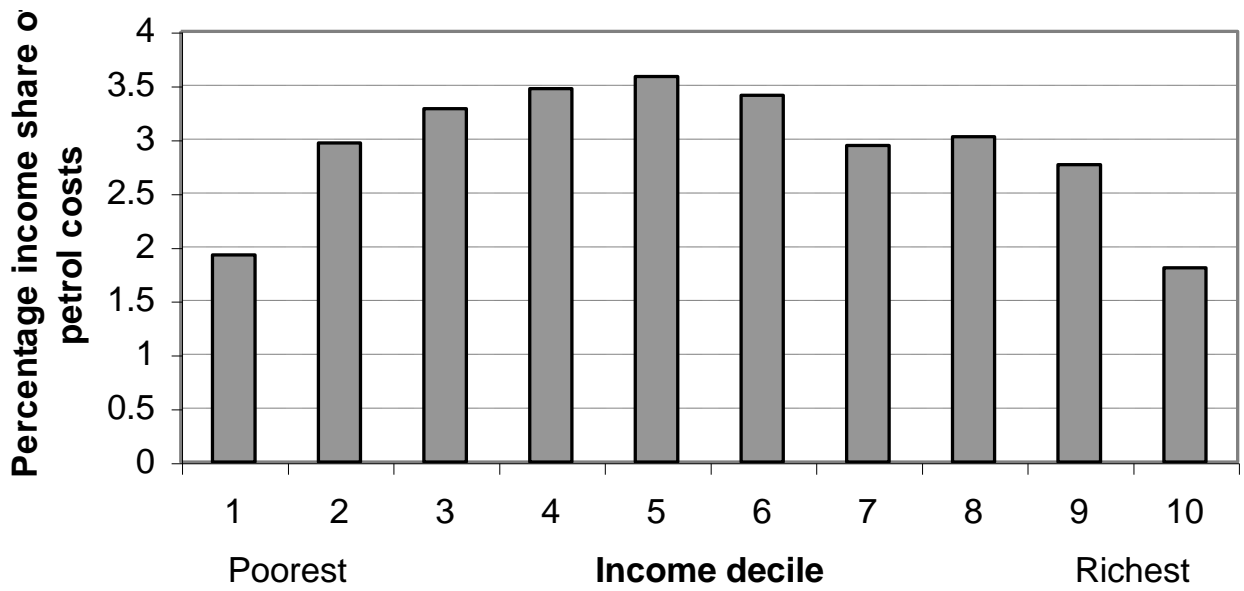

Source: Family Expenditure Survey 1999-2000

FIGURE 3 Income share of gasoline costs for car-owning households by income decile

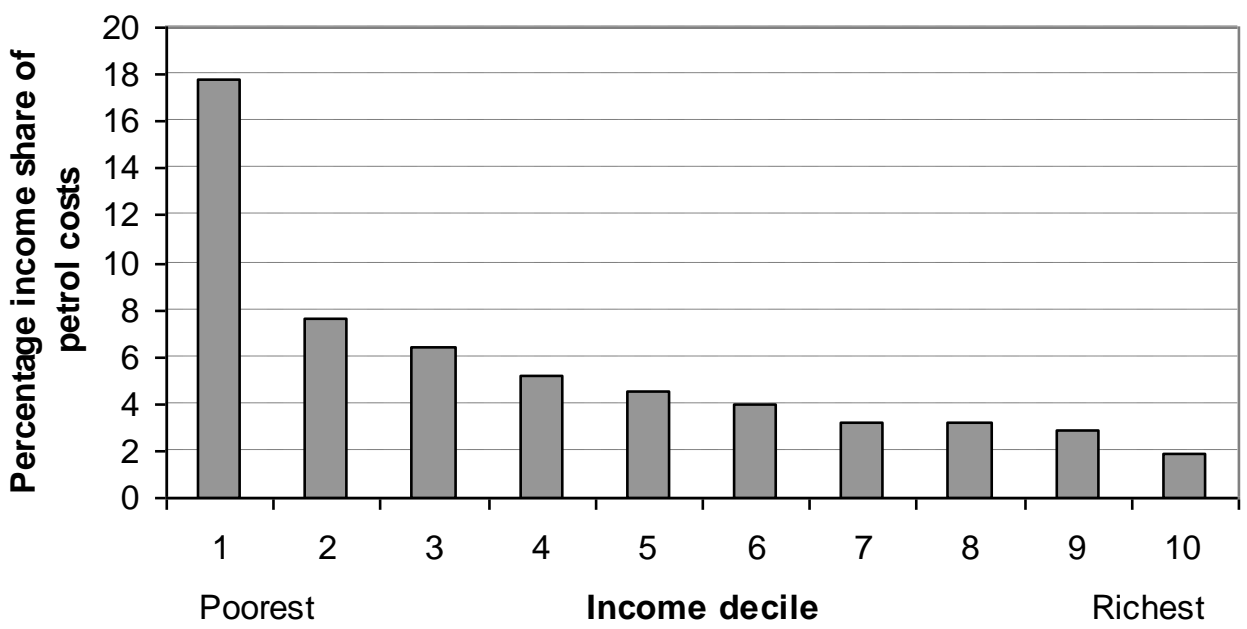

Source: Family Expenditure Survey 1999-2000

Because the budget share of road fuel varies across the population, it is likely that the burden of a rise in fuel taxes will also vary across different levels of household income. From the relationship between income and budget share shown in Figure 2, it would seem likely that lowincome car-owning households would suffer relatively badly from such a rise, compared to higher-income households, because expenditure on road fuel accounts for a larger share of their income. 
Blow and Crawford (3) and Smith (5) measure the impact of a rise in fuel duty in terms of a cost-of-living index, which compares the cost of achieving a given level of economic welfare before the tax increase with the cost of achieving the same level of economic welfare after the tax increase. Using data for the UK from the National Travel Survey (NTS) from 1988 to 1993, Blow and Crawford (3) estimate the average increase in the cost-of-living index of a $6 \%$ real increase in duties (which corresponds to the escalator that was in use until November 1999) across all households to be $0.17 \%$, rising to $0.25 \%$ for car-owning households alone. They show that the effect of a duty increase varies systematically across income deciles, with lower-income households being affected more severely than higher-income households. Additionally, the effect of a duty increase is observed to fall with population density, so that the cost-of-living index rises more for rural than urban households. Smith (5) confirms this generalized pattern using income, price and mileage data extrapolated to 1997, showing that a $6 \%$ real increase in duty raised the cost of living by over $0.35 \%$ for the poorest income decile, falling to around $0.15 \%$ for the richest income decile. Again, the rise in the cost-of-living index is shown to be higher for rural households than for urban households.

From these figures, it would appear that there is cause for concern about the distributional effects of gasoline taxation in the UK because those who can least afford it (ie, low-income households) and those who depend upon private vehicles in the absence of high-quality public transport services (ie, rural households) are most severely affected by a rise in fuel duty. However, the question remains as to whether the findings presented in Blow and Crawford (3) and Smith (5) are still relevant today and, if so, whether the nature of the effects they described has changed at all. The rest of this analysis will be devoted to addressing this question.

\section{THE MODEL}

Following Blow and Crawford (3), a cost-of-living index is used in this paper to measure the welfare effects of a rise in gasoline taxation for different groups of households, which may then be used to assess the distributional effects of gasoline taxation. If the pre-reform level of welfare is denoted $U_{0}$, the set of pre-reform prices $p_{0}$, the set of post-reform prices $p_{T}$ and the cost function (which is the minimum expenditure necessary to reach a certain level of welfare, $U$, given a set of prices, $p)$ is $c(p, U)$, then the cost-of-living index is:

$$
\text { Cost-of-living index }=\frac{c\left(p_{T}, U_{0}\right)}{c\left(p_{0}, U_{0}\right)}
$$

In order to measure the distributional consequences of gasoline taxation in the UK, cost-ofliving indices will be constructed for different groups both across the range of household incomes and across population densities. A $6 \%$ real rise in fuel duty will be considered. Bearing in mind that the escalator was ended in November 1999, this figure may seem somewhat arbitrary. The objective of the exercise however is to assess what the distributional impacts would be if there was such an increase. $6 \%$ also represents government policy in the run-up to the 2000 fuel protests. Finally, choosing a figure of $6 \%$ also allows direct comparison with Blow and Crawford (3) and Smith (5). However, since it is difficult to derive the true cost function used in the cost-of-living index, an approximation to it will be used in its place. This will be considered in the next section. 


\section{Behavioral responses}

One purpose of gasoline taxation, apart of course of raising revenues, is to change individuals' behavior, namely the amount of fuel they consume and, to a lesser extent, the number of miles they drive. It therefore becomes important to accommodate behavioral changes when calculating a cost-of-living index to assess the welfare effect of a rise in gasoline taxation if the results are not to be unnecessarily biased.

A first-order approximation to the welfare effect holds demand constant. The welfare effect would simply be the difference in expenditure on the same set of goods before and after the tax reform, and the cost-of-living index would be approximated by:

$$
\text { Cost-of-living index } \approx \frac{p_{T} q_{0}}{p_{0} q_{0}}
$$

It should be noted that this index is expressed in terms of the set of goods bought before the reform, $q_{0}$, rather than the pre-reform level of welfare used in equation (1).

Banks et al (6) present data that suggest that in the case of tax reforms, which often involve substantial rather than marginal changes in price, so that substitution effects are likely to be nontrivial, a second-order approximation to the welfare effect will be an improvement over a firstorder one, which does not allow for any behavioral response. First-order approximations systematically over-estimate the social welfare effect of price changes, while second-order approximations act to correct this bias; for a price increase of $10-20 \%$, they calculate that a second-order term reduces this bias by as much as 5-10 percentage points of the total welfare effect.

Following Blow and Crawford (3), a second-order approximation to the welfare effect will be used here. Such an approximation incorporates a demand response, which requires the welfareconstant demand response to be calculated. The cost-of-living index is approximated by

$$
\frac{c\left(p_{T}, U_{0}\right)}{c\left(p_{0}, U_{0}\right)} \approx \frac{p_{T} q_{0}}{p_{0} q_{0}}+\left.\frac{\left(p_{T}-p_{0}\right)^{2}}{2 p_{0} q_{0}} \cdot \frac{\partial q}{\partial p}\right|_{U=U_{0}}
$$

where the welfare-constant demand response is given by (4), in which $e_{y}$ and $e_{p}$ are the income and own-price elasticities of the demand for road fuel, respectively:

$$
\left.\frac{\partial q}{\partial p}\right|_{U=U_{0}}=e_{y}\left(\frac{q}{y}\right) q+e_{p}\left(\frac{q}{p}\right)
$$

In order to estimate a second-order approximation to the cost-of-living index, these elasticities need to be estimated.

\section{Model specification}

A simple model of car usage based upon that presented in Blow and Crawford (3) will be used to estimate the behavioral response of drivers to the increased cost of mileage brought about by a 
rise in gasoline taxation. The results produced will be used to calculate the welfare-constant demand response used in estimating the effect of a rise in gasoline taxation upon welfare.

Espey (7) surveys a range of empirical estimates of income and own-price elasticities for the demand for road fuel, and presents a list of variables that have proved statistically significant in these models. They include car ownership, fuel efficiency, regional dummy variables, population density, the availability of public transport and the ages of the individuals surveyed. While most of these variables are used both here and in Blow and Crawford (3), both models are limited to the short-run only and do not allow for changes in the vehicle stock. It is therefore likely that the long-run response of fuel consumption and miles driven will differ from the response estimated here, which only allows for changes in mileage given the current stock of cars. The model used here also differs from that of Blow and Crawford (3) by omitting the term they use to correct for selectivity bias, which is caused by the fact that mileages are only observed for those households whose demand for mileage is sufficient for them to own a car. This term requires a separate equation to be estimated in addition to the mileage equation, and so has been omitted from the model presented here for reasons of simplicity. Additionally, variables such as the real price of public transport and the proportion of company cars in the household have been omitted from the model used here for the same reason. Although Blow and Crawford (3) estimate separate equations for one-car and two-car households, because the 1998 edition of the NTS contains less data than the 1988-1993 data set used by them, a single equation for all car-owning households is estimated here in order to achieve sufficiently low standard errors.

The model estimated here is a log-linear model that regresses log mileage against the real cost per mile (CPM) of driving, which is the price of road fuel divided by the fuel efficiency of the household's vehicles. This functional form tells us the relationship between proportional changes in mileage and absolute changes in CPM. It also allows the demand response to CPM to vary with the level of demand, which is a key issue in assessing the distributional effects of a rise in CPM due to a rise in gasoline taxation, whereas a log-log model imposes the restriction that the own-price elasticity of demand for mileage is constant for all households. Again following Blow and Crawford (3), the issue of the endogeneity of CPM is dealt with by using the average CPM for all households in the same region as an instrument for any particular household's CPM. The endogeneity problem arises because a correlation between demand for miles and CPM may be produced by households with a high demand for mileage seeking to reduce their CPM through mechanisms such as driving more slowly in order to conserve fuel. The regional average of CPM is a reasonable predictor of households' CPM, but is not endogenous because it is not a choice variable in this short-run model.

A full list of the variables used in the mileage equation used here is presented in Table 1. It should be noted that the dummy variables for full-time employment, unskilled manual work, population density $>35$ persons per hectare in the household's local authority and living in London have been omitted from the estimated equation to avoid perfect multicollinearity. The estimated coefficients therefore represent deviations from a baseline model of a head of household in full-time, unskilled manual employment living in a local authority in London with more than 35 persons per hectare. 
TABLE 1 Variables used in mileage equation

\begin{tabular}{|c|c|}
\hline Dependent Variable & Independent Variables \\
\hline $\ln$ (miles) & $\begin{array}{l}\text { Real cost per mile } \\
\ln (\text { real income) } \\
{\left[\ln (\text { real income }]^{2}\right.} \\
\text { Age of head of household } \\
\text { [Age of head of household] }{ }^{2} \\
\text { Part-time employee } \\
\text { Unemployed } \\
\text { Retired } \\
\text { Domestic work } \\
\text { Self-employed } \\
\text { Professional } \\
\text { Non-manual } \\
\text { Skilled manual } \\
\text { Number of children } \\
\text { Bus available and frequent } \\
\text { Rail available and frequent } \\
\text { Pop. density of local authority }<3.5 \text { people per hectare } \\
\text { Pop. density of local authority } 3.5-9.9 \text { people per hectare } \\
\text { Pop. density of local authority } 10-19.9 \text { people per hectare } \\
\text { Pop. density of local authority } 20.34 .9 \text { people per hectare } \\
\text { Standard region } \\
\text { North } \\
\text { Yorkshire \& Humberside } \\
\text { East Midlands } \\
\text { East Anglia } \\
\text { South East } \\
\text { South West } \\
\text { West Midlands } \\
\text { North West } \\
\text { Wales \& Scotland }\end{array}$ \\
\hline
\end{tabular}

\section{Data}

The annual NTS contains extensive cross-sectional data on individuals' and households' travelling habits as well as other characteristics such as individuals' income, age, and access to public transport. Blow and Crawford (3) use data from the NTS for 1988 to 1993 to estimate their mileage equation, but more recent data have since become available and the 1998 edition of the NTS, sourced from the UK Data Archive at the University of Essex, will be used for the purposes of this analysis. However, extensive work was required in adapting the NTS data into a format suitable for running household-level regressions. 
Once the behavioral response of drivers to a rise in gasoline taxation has been estimated, this information will be combined with income and expenditure data taken from the 1999-2000 edition of the Family Expenditure Survey to estimate the impact of the tax reform upon households' cost-of-living indices. Again, this data has been sourced from the UK Data Archive at the University of Essex.

\section{Elasticities}

Using the estimated coefficients from the model presented above, income and own-price elasticities for the demand for road fuel will be derived as follows for each of the income and population density categories considered. These categories are produced by dividing the sample into income and population density quintiles, creating a total of 25 discrete categories ranging from the poorest households living in the least densely populated areas to the richest households living in the most densely populated areas. Since log mileage is being regressed against CPM, the own-price elasticity for mileage is

$$
\frac{\partial q}{\partial p} \cdot \frac{p}{q}=\frac{\partial \ln q}{\partial p} \cdot p
$$

where $\partial \ln q / \partial p$ is the estimated coefficient on CPM and $p$ is the average CPM for the category being considered. Since both $\log ($ income $)$ and $(\log [\text { income }])^{2}$ are included as explanatory variables in the model, the income elasticity for mileage is

$$
\frac{\partial q}{\partial y} \cdot \frac{y}{q}=a+2 b \ln y
$$

where $a$ and $b$ are the estimated coefficients on $\log ($ income) and (log[income $])^{2}$, respectively, and $\ln y$ is the average of log income for the category being considered.

\section{RESULTS}

The results of estimating the mileage equation using instrumental variables estimation are presented in Table 2. The results of the White test for heteroskedasticity and Ramsey RESET test for functional form fail to reject the null hypotheses of homoskedasticity and a correctly specified functional form, and thus the estimated model appears to satisfy the Gauss-Markov assumptions required to interpret the estimated coefficients and standard errors. The F-statistic indicates that the variables are jointly significant, while the value of $\bar{R}^{2}$ indicates that roughly $25 \%$ of the variation in mileage is explained by the model. This figure is comparable to the $\bar{R}^{2}$ value of 0.2941 yielded by the single-car household regression presented in Blow and Crawford (3), and the lower value presented here can be explained by the use of different data sets and the differences between the variables used by the two models, as explained above. 


\section{TABLE 2 Mileage equation results}

Dependent variable: $\ln ($ miles)

Instrumental variables estimation, exclusion restrictions: regional average fuel price and regional average fuel efficiency.

\begin{tabular}{|c|c|c|c|}
\hline Variable & Coefficient & Standard error & Probability value \\
\hline Real cost per mile & -5.463368 & 1.270072 & .0000 \\
\hline $\ln ($ real income $)$ & 1.234870 & .045068 & .0000 \\
\hline$[\ln (\text { real income })]^{2}$ & -.109789 & .009501 & .0000 \\
\hline Age of head of household & .043136 & .005245 & .0000 \\
\hline [Age of head of household] ${ }^{2}$ & -.000511 & .000005 & .0000 \\
\hline Part-time employee & -.063027 & .055450 & .2557 \\
\hline Unemployed & -.060200 & .093283 & .5187 \\
\hline Retired & -.147262 & .045415 & .0012 \\
\hline Domestic work & -.328915 & .088462 & .0002 \\
\hline Self-employed & -.077401 & .034520 & .0250 \\
\hline Professional & .181547 & .044000 & .0000 \\
\hline Non-manual & -.011004 & .030021 & .7140 \\
\hline Skilled manual & -.150971 & .045488 & .0009 \\
\hline Number of children & .127967 & .013850 & .0000 \\
\hline Bus available and frequent & -.207934 & .037433 & .0000 \\
\hline Rail available and frequent & -.106869 & .035567 & .0027 \\
\hline Pop. density of LA < 3.5 p.p.ha & .415392 & .049966 & .0000 \\
\hline Pop. density of LA 3.5-9.9 p.p.ha & .308604 & .052064 & .0000 \\
\hline Pop. density of LA $10-19.9$ p.p.ha & .236058 & .053123 & .0000 \\
\hline Pop. density of LA 20-34.9 p.p.ha & .170632 & .050229 & .0007 \\
\hline Standard region & & & \\
\hline North & .193626 & .067446 & .0041 \\
\hline Yorkshire \& Humberside & .006604 & .056826 & .9075 \\
\hline East Midlands & .031051 & .055287 & .5744 \\
\hline East Anglia & -.042991 & .074870 & .5658 \\
\hline South East & .098021 & .041531 & .0183 \\
\hline South West & -.010362 & .053457 & .8463 \\
\hline West Midlands & .217996 & .050836 & .0000 \\
\hline North West & .131263 & .051882 & .0114 \\
\hline Wales \& Scotland & .073748 & .064760 & .2548 \\
\hline Constant & 7.202291 & .254319 & .0000 \\
\hline $\mathrm{N}=6230$ & \multicolumn{2}{|c|}{$\mathrm{F}(30,6199)=72.19969$} & $\mathrm{R}^{2}=0.252453$ \\
\hline $\bar{R}^{2}=0.248956$ & \multicolumn{2}{|c|}{ White F-stat $=0.160120$} & $\begin{array}{l}\text { RESET F-stat }= \\
0.594963\end{array}$ \\
\hline
\end{tabular}


Table 3 summarizes the estimated coefficients and the effects of the variables upon mileage. The tests for statistical significance were carried out at the 5\% significance levels. The statistical significance of the key variables of real cost per mile and real household income mean that the simulated effects that tax increases have on households will be statistically significantly different from a first-order approximation that does not take behavioral responses into account. As discussed above, this means that a second-order approximation to the welfare effect will be significantly more accurate than a first-order approximation.

TABLE 3 Summary of the main features of the regression results

\begin{tabular}{|c|c|}
\hline Variable & Results \\
\hline Real cost per mile & $\begin{array}{l}\text { Real cost per mile has a negative and statistically } \\
\text { significant effect on mileage, such that an increase in the } \\
\text { real cost per mile causes a drop in mileage. }\end{array}$ \\
\hline Real household income & $\begin{array}{l}\text { Real income has a positive and statistically significant } \\
\text { effect on mileage, but the rate of increase of mileage } \\
\text { declines with income. }\end{array}$ \\
\hline Age of head of household & $\begin{array}{l}\text { Age has a positive and statistically significant effect on } \\
\text { mileage, but the rate of increase of mileage declines with } \\
\text { age. }\end{array}$ \\
\hline Number of children & $\begin{array}{l}\text { The number of children in the household has a positive } \\
\text { and significant effect on mileage. }\end{array}$ \\
\hline $\begin{array}{l}\text { Employment status of head of } \\
\text { household }\end{array}$ & $\begin{array}{l}\text { All categories have lower mileage compared to full-time } \\
\text { workers, although the effect is statistically significant } \\
\text { only for the retired. }\end{array}$ \\
\hline Occupational class & $\begin{array}{l}\text { Professionals have increased mileage, and skilled manual } \\
\text { workers reduced mileage, compared to an unskilled } \\
\text { manual worker. The difference for non-manual workers } \\
\text { is not statistically significant. }\end{array}$ \\
\hline Availability of public transport & $\begin{array}{l}\text { Available and frequent public transport services have a } \\
\text { statistically significant negative impact on mileage. }\end{array}$ \\
\hline Population density & $\begin{array}{l}\text { Households in the least densely populated areas have } \\
\text { significantly increased mileages compared to those in the } \\
\text { most densely populated areas. }\end{array}$ \\
\hline Region & $\begin{array}{l}\text { Households in the North, the South East and the West } \\
\text { Midlands have significantly increased mileages } \\
\text { compared to London. None of the other standard regions } \\
\text { have significantly different mileages. }\end{array}$ \\
\hline
\end{tabular}




\section{Estimated elasticities}

The results from estimating the mileage equation have been used to calculate the own-price and income elasticities of the demand for mileage. These were calculated for 25 discrete groups of households, divided according to their income and the population density of their local authority. Figures 4 and 5 present the distribution of the own-price and income elasticities across these groups.

As can be seen from the figures, the own-price elasticity generally declines with income and increases with population density, while the income elasticity declines steeply with income and shows no consistent pattern over population density. The greatest price sensitivity is shown by the poorest households living in the most densely populated areas, with an elasticity of -0.9271 , while the smallest price response is shown by middle-income households in rural areas, with an elasticity of -0.749 . Income elasticities vary between 0.6335 for the poorest households in the most densely populated areas, down to 0.0681 for the richest households living in rural areas.

FIGURE 4 The distribution of the own-price elasticity of mileage, by income group and population density

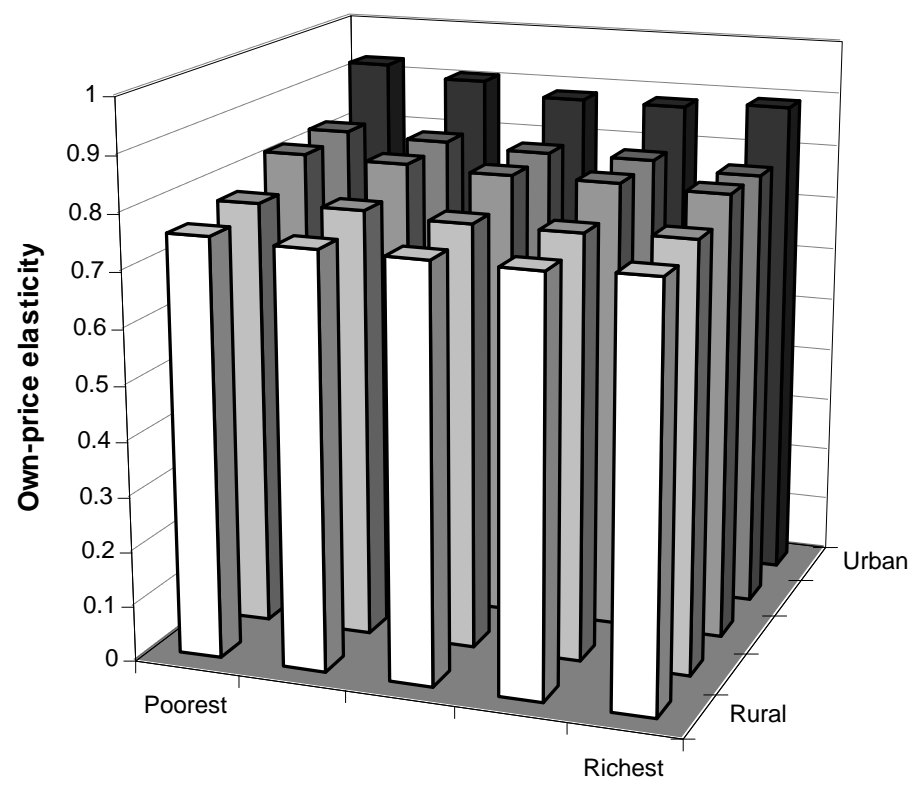

Source: Own calculations 
FIGURE 5 The distribution of the income elasticity of mileage, by income group and population density

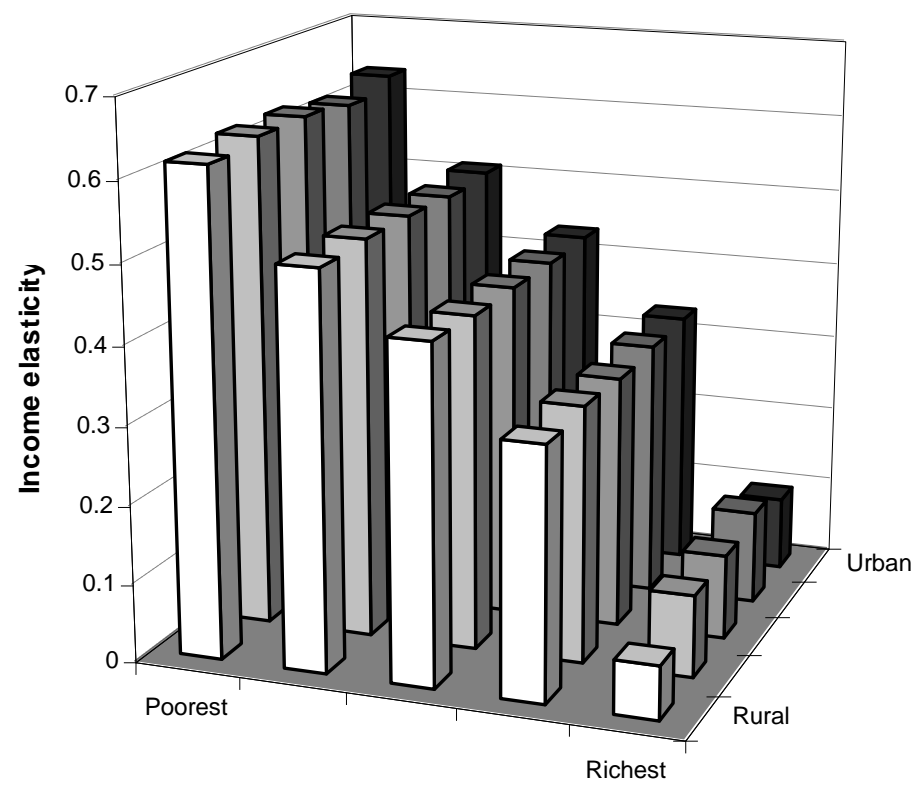

Source: Own calculations

While the distribution of elasticities across income and population density is similar to those shown in Blow and Crawford (3), the magnitude and variability of those presented here are somewhat larger. The demand for mileage is rather more price-elastic, and more income-elastic for poorer households, although less income-elastic for richer households. Although Espey (7) suggests that the demand for mileage is becoming more price-elastic and less income-elastic over time, given the relatively short gap between the data used here and that used in Blow and Crawford (3), it is likely that other factors are responsible for much of the difference between the estimated elasticities. These factors include the possibility that the elasticities have been evaluated at different points on households' demand curves and sampling variation.

Although higher than the averages reported by Goodwin (8), Espey (7), Graham and Glaister (9) and Goodwin et al (10) the elasticities estimated in this study fall within the ranges reported by Espey (7), who reviews a number of articles published over a period of over 30 years. Graham and Glaister (9) report numbers showing that short-run price elasticities from studies based on household data tend to be higher than those from studies based on aggregate level data, which typically include commercial and consumer demand at a national or sub-national level. This may well explain the higher estimates produced in the present study. 


\section{Cost-of-living indices}

Using the estimated elasticities and the data on households' expenditure on gasoline and the other components of the cost per mile of motoring taken from the 1999-2000 Family Expenditure Survey, cost-of-living indices were constructed to analyze the impact of an increase in road fuel duties on households' welfare. As explained above, a $6 \%$ real increase in the duty on unleaded gasoline was considered.

Using the latest prices (for October 2004), the duty on unleaded gasoline was 47.1 pence per litre or $57.8 \%$ of the retail price of unleaded (81.5 pence per litre). A $6 \%$ real rise in fuel duty raises the retail price of unleaded by $4 \%$ and the cost per mile of motoring by $1.9 \%$. This price increase is fed into the second-order approximation to the welfare effect presented in equation (3), along with the estimated elasticities, in order to estimate the percentage increase in the costof-living index for each income and population density quintile in the car-owning population. The results are presented in Figures 6 and 7. Figure 8 shows the effect of the same duty increase for all households, rather than car-owning households alone.

Figure 6 shows that raising gasoline taxation has a strongly regressive effect on households' cost-of-living when car-owning households alone are considered. While a $6 \%$ real increase in fuel duty raises the cost-of-living index of the richest group of households by $0.11 \%$, it raises that of the poorest category of households by $0.76 \%$-almost seven times as much. This regressive effect can be explained by the fact that low-income car-owning households spend a greater proportion of their income on gasoline than higher-income households (as Figure 3 shows), so a rise in gasoline taxation that raises the retail price of gasoline will affect them more severely. Figure 8, however, presents a rather different picture of the effects of increased gasoline taxation when all households are considered, rather than just car-owning households. The cost-of-living index effect of a real increase in fuel duty is highest for middle-income groups. The difference between Figures 6 and 8 can be explained in terms of car-ownership: lowincome households are less likely to own a car and so, although an increase in gasoline taxation has a strong impact on those low-income households that do own a car, the poorest income quintile as a whole is less strongly affected.

Figure 7 shows that a real increase in duty raises the cost-of-living index of car-owning households living in rural areas more than it does for car-owning households living in urban areas. It would be reasonable to suggest that this could be due to rural households having less flexibility in choosing their mileage than urban households, who are more likely to be able to substitute public transport, walking or cycling for private motoring.

While the elasticities presented here are generally higher than those in Blow and Crawford (3), the effect of a $6 \%$ real increase in fuel duty on the cost-of-living indices is remarkably similar. 
FIGURE 6 Effect of a $6 \%$ real increase in duty on cost-of-living for car-owning households, by income quintile

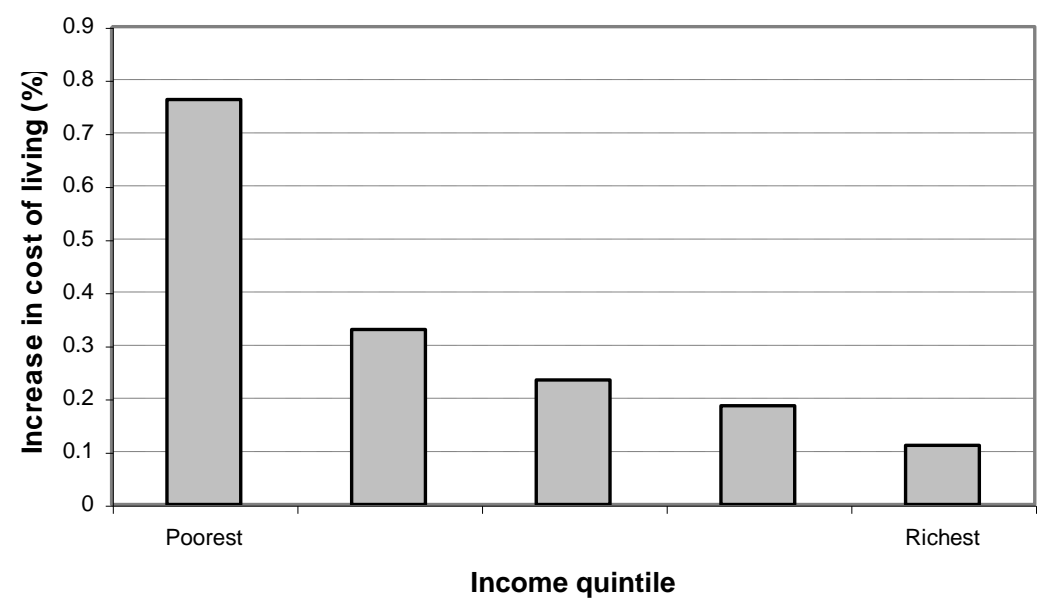

Source: Own calculations

FIGURE 7 Effect of a $6 \%$ real increase in duty on cost-of-living for car-owning households, by population density

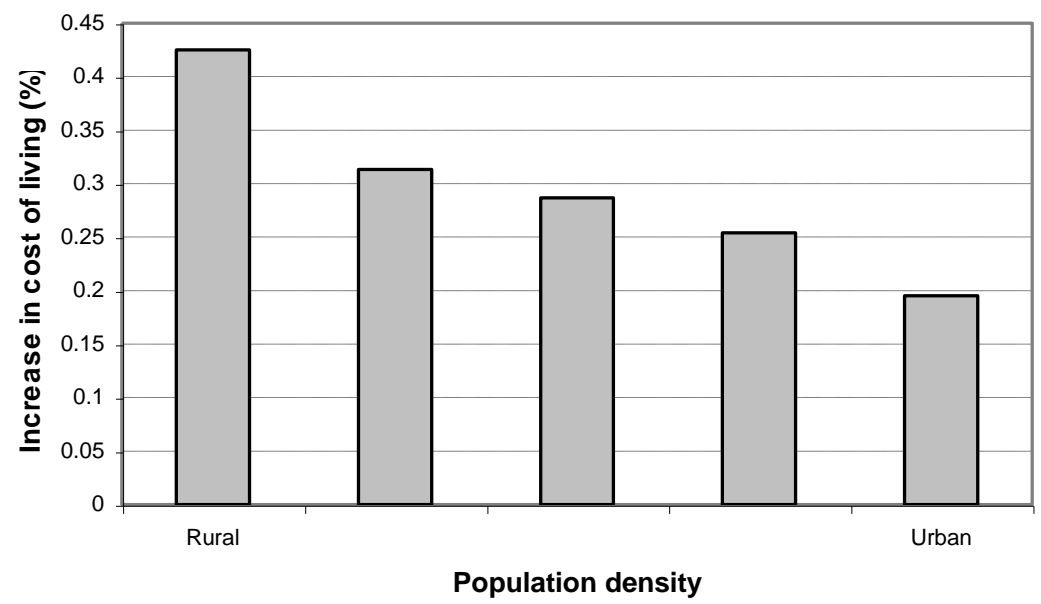

Source: Own calculations 


\section{FIGURE 8 Effect of a $6 \%$ real increase in duty on cost-of-living for all households, by income quintile}

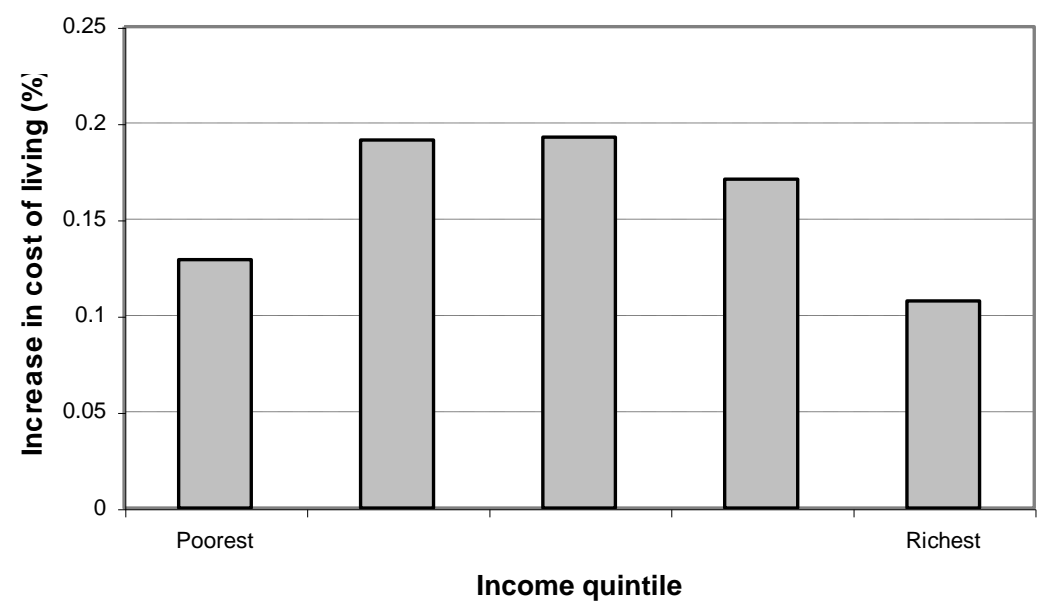

Source: Own calculations

\section{CONCLUSIONS}

The fuel protests of 2000 brought the issue of gasoline taxation to the forefront of public debate, and much of the language used by the protestors was expressed in terms of concern for lowincome and rural households, who were widely perceived as suffering disproportionately from rising gasoline taxation. This analysis has attempted to assess the validity of such concerns.

In this study, a mileage equation to predict the effect of a rise in gasoline taxation upon motorists' mileage via the increase in the cost per mile of motoring that it produces has been estimated. It has been shown that a $1 \%$ real rise in CPM will decrease mileage by $0.93 \%$ for the poorest households living in the most densely populated areas, falling to $0.75 \%$ for middleincome households in rural areas, ceteris paribus. Gasoline taxation therefore appears to be somewhat effective in reducing households' mileage.

The behavioral response estimated by the mileage equation was then used to assess the effect of a rise in gasoline taxation upon households' welfare by constructing cost-of-living indices that measure the percentage increase in households' income that they would need to achieve their pre-tax increase level of welfare. When all households are considered, middle-income households suffer the greatest increase in their cost-of-living index. However, amongst carowning households, an increase in gasoline taxation appears to be strongly regressive. Lowincome households are severely affected compared to all other income groups, and the welfare effect of the tax reform declines as income increases. Additionally, households in rural areas are more seriously affected by a rise in gasoline taxation than households in urban areas.

From these results, it would appear that the arguments advanced in terms of the distributional consequences of gasoline taxation by the fuel protesters in the summer of 2000 are justified. While if all households are considered, middle-income households appear to suffer the burden of rising gasoline taxation, it is strongly regressive if car-owning households alone are considered. 
If fuel duties were increased in the UK as had been originally planned for September 2004, there would be pervasive distributional impacts.

However, it should be remembered that the model presented here is based upon a short-run mileage equation estimated using cross-sectional data. In the long-run, households have greater freedom to change their mileage in response to a rise in gasoline taxation because they can change the number and efficiency of the vehicles they own. This means that the income and own-price elasticities of the demand for mileage will be higher, and it could be expected that the welfare effect of a tax reform will be reduced.

\section{ACKNOWLEDGEMENTS}

The authors are grateful to the Office for National Statistics and the UK Data Archive at the University of Essex for the provision of data from the 1998 edition of the National Travel Survey and the 1999-2000 edition of the Family Expenditure Survey. Georgina Santos gratefully acknowledges support from the British Academy whilst she was at Cambridge, where most of this study was conducted, and from the Rees Jeffreys Road Fund, that supports her at Oxford, where the study was finished.

\section{REFERENCES}

1. Johnson P., McKay S. and S. Smith (1990), The distributional consequences of environmental taxes, Commentary $\mathrm{N}^{\circ} 23$, The Institute for Fiscal Studies, London.

2. Wiese, A., Rose, A. and G. Schluter (1995), Motor-fuel taxes and household welfare - an applied general equilibrium analysis', Land Economics, 71(2), 229-243.

3. Blow, L. and Crawford, I. (1997), The distributional effects of taxes on private motoring, Commentary $\mathrm{N}^{\circ}$ 65, The Institute for Fiscal Studies, London.

4. Asensio, J., Matas, A. and J. Raymond (2003), 'Gasoline expenditure and redistributive effects of its taxation in Spain', Transportation Research A, 37(1), 49-69.

5. Smith, Z. (2000), The Gasoline Tax Debate, Institute for Fiscal Studies Briefing Note No. 8. www.ifs.org.uk/consume/gasoline.pdf

6. Banks, J., Blundell, R. and A. Lewbel (1996), 'Tax reform and welfare measurement: do we need demand system estimation?', Economic Journal, 106 (September), 1227-41.

7. Espey, M. (1998), 'Gasoline demand revisited: an international meta-analysis of elasticities', Energy Economics, 20(3), 273-295.

8. Goodwin, P. (1992), 'A review of new demand elasticities with special reference to short and long run effects of price changes', Journal of Transport Economics and Policy, 26(2), 155-169.

9. Graham, D. and S. Glaister (2002), 'The demand for automobile fuel: A survey of elasticities', Journal of Transport Economics and Policy, 36(1), 1-25.

10. Goodwin, P., Dargay, J. and M. Hanly (2004), 'Elasticities of road traffic and fuel consumption with respect to price and income: A review', Transport Reviews, 24 (May), 275-292. 